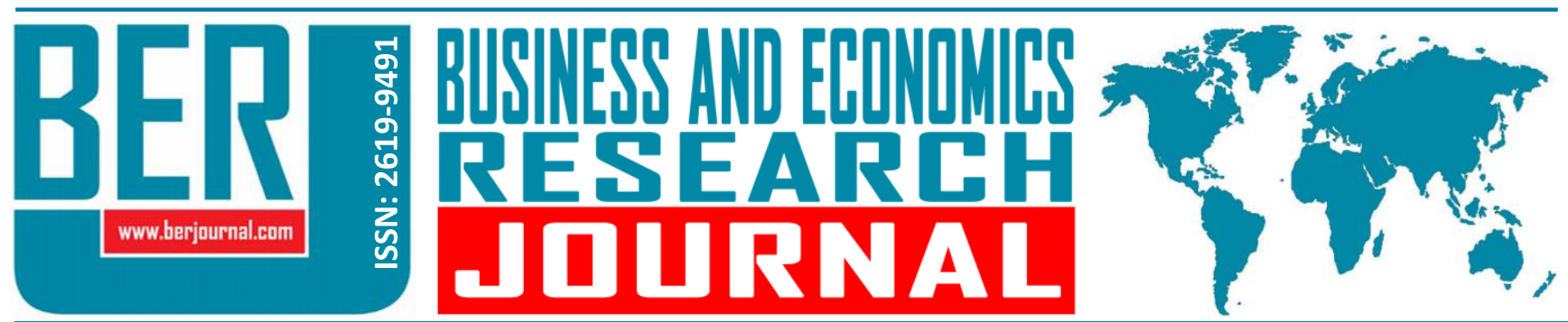

Business and Economics Research Journal Vol. 10, No. 3 Special Issue, 2019, pp. 735-748 doi: 10.20409/berj.2019.197

\section{Örgüt Temelli Özsaygının İş Performansına Etkisinde Psikolojik İyi Oluş ve Çalışmaya Tutkunluğun Aracılık Rolü*}

Anahtar Sözcükler: Örgüt Temelli Öz Saygı, ìş Performansı, Psikolojik İyi Oluş, Çalışmaya Tutkunluk

JEL: M10, M12, M20

$\begin{array}{ll}\text { Geliş } & : 27 \text { Şubat 2019 } \\ \text { Düzeltme } & : 06 \text { Mart 2019 } \\ \text { Kabul } & : 25 \text { Mart 2019 } \\ \text { Tür } & \text { : Araştırma }\end{array}$

Keywords: OrganizationBased Self-Esteem, Job Performance, Psychological Well-Being, Work Engagement JEL: M10, M12, M20

Received : 27 February 2019 Revised : 06 March 2019 Accepted : 25 March 2019 Type : Research 


\section{Giriş}

Örgütlerin belirsiz çevre koşullarında rekabet gücünü ve büyümesini sürdürmesinde en önemli rol çalışanlara düşmektedir. Çalışanların ortaya koyacakları iş performansları örgütlerin bu başarısında belirleyici bir konumda olabilecektir (Raich ve Ho, 2017). Dolayısıyla örgütler çalışanlarından proaktif ve dinamik olmaları, sorumluluk almaları ve yüksek performansa ulaşmaları ve bunları sağlayabilmeleri için de sadece fiziksel değil aynı zamanda bilişsel ve duygusal olarak tutkulu olmalarını beklemektedir (Kahn, 1990; Bakker ve Leiter, 2010; Wadhawan, 2016). Ancak çalışanlardan beklentilerin karşılanmasının daima arzu edilen bir sonuç olması yanı sıra, bu arzunun gerçekleşmesi çeşitli faktörlere ve bu faktörlerin bir etkileşim kurabilme sürecine bağlı olmaktadır. Bu bağlamda örgütlerde söz konusu beklentinin gerçekleşmesinde çalışanların olumlu benlik algılaması, çalışanların kendilerini geliştirme ve rol performansını yerine getirmesine yardımcı olan maddi olmayan önemli bir güç olarak görülmektedir (Judge, Erez ve Bono, 1998).

Örgüt temelli özsaygı, bireyin çalıştığı örgütün bir üyesi olarak kişisel yeterliliği ve değerliliğine dair bir değerlendirmesi olup; örgüt temelli özsaygısı yüksek çalışanlar örgütlerinde kendilerinin değerli, anlamlı ve önemli olduklarına inanırlar (Gardner, Dyne ve Pierce, 2004). Yüksek örgüt temelli özsaygının yüksek iş performansına yol açabileceği mantıklı olarak görünmesine ve bu iki değişken arasında pozitif ilişkiyi destekleyen çeşitli çalışmalar (Gardner ve Pierce, 1998; Hui ve Lee, 2000; Gardner vd., 2004; Pierce ve Gardner, 2004; Bowling, Eschleman, Wang, Kirkendall ve Alarcon, 2010; Hahn ve Mathews, 2018) olmasına rağmen, bu iki değişken arasındaki mekanizmaya etki edebilecek faktör ya da faktörlere dair az sayıda çalışma söz konusudur. Bu rolü yerine getirme potansiyeline sahip bireysel yapılardan bazıları psikolojik iyi oluş ve çalışmaya tutkunluktur. Dolayısıyla örgüt temelli özsaygının iş performansına etkisinin psikolojik iyi oluş ve çalışmaya tutkunluk üzerinden nasıl ortaya çıkabileceğinin incelenmesi önem arz etmektedir.

Yazında psikolojik iyi oluşun yaratıcılık, yenilikçilik, çalışmaya tutkunluk, başarı hissi ve iş performansı gibi örgütler için önemli olan konulardaki rolüne dikkati çekilmektedir (Garcea, Harrington ve Linley, 2010). Psikolojik iyi oluş, pozitif psikolojinin merkezi yapılarından biri olarak bireyin yaşamının olumsuz özellikleri yerine olumlu özelliklerine odaklanmaktadır (Raich ve Ho, 2017). Seligman'a (2011) göre pozitif duygular, tutkunluk, ilişkiler, anlamlılık ve başarma bireyin iyi oluşu ve mutluluğunda önemli özellikler olup, bu özelliklerin bireyin yaşamındaki artışı psikolojik iyi oluşunun güçlenmesine ve böylece iş performansının artışına katkıda bulunabilecektir.

Çalışanların performanslarıyla ilişkili öncüllerden birisi de çalışmaya tutkunluktur (Rich, Lepine ve Crawford, 2010; Schaufeli, Salanova, González-Romá ve Bakker, 2002). Çalışanların hem bireysel hem de örgütsel kaynaklar sayesinde kendilerinden beklenen iş taleplerini karşılaması ve işlerini yüksek bir dinçlik, adanma ve yoğunlaşma düzeyi ile yerine getirmeleri sonucu çalışmaya tutkunluk ve böylece de rol performansı, ekstra rol performansı, yaratıcılık ve yüksek finansal getiri gibi pozitif sonuçlar ortaya çıkabilmektedir (Bakker ve Demerouti, 2008).

Örgüt temelli özsaygının iş performansı üzerinde pozitif bir etkiye sahip olduğuna dair çalışmalar mevcuttur. Ayrıca ilgili yazında örgüt temelli özsaygının psikolojik iyi oluş (Pierce, Gardner ve Crowley, 2015) ve çalışmaya tutkunluk (Rotich, 2016) üzerine pozitif etkilerine ilişkin çalışmalar da bulunmaktadır. Ancak bu çalışmaların sayısı sınırlı olmakla birlikte, ilgili yazında örgüt temelli özsaygının iş performansı üzerine etkisinde psikolojik iyi oluş ile çalışmaya tutkunluğun aracılık rollerini birlikte araştıran herhangi bir çalışmaya rastlanmamıştır. Bu çalışmanın temel amacı, örgüt temelli özsaygının iş performansı üzerine etkisinde psikolojik iyi oluş ile çalışmaya tutkunluğun aracılık rollerini incelemektir. Böyle bir çalışmanın yapılmasının iş performansı üzerinde etkili olan faktörlere ve bu faktörlerin birbirleriyle etkileşimlerine dair ilgili yazına katkılar sunması, ayrıca bağımsız ve aracı değişkenlerin geliştirilebilir ve yönetilebilir yapılar olarak pratikte özellikle insan kaynakları yöneticilerine yapabilecekleri uygulamalara ışık tutması beklenmektedir. Örgüt temelli özsaygı, psikolojik iyi oluş ve çalışmaya tutkunluk gibi özellikler bakımından donanmış çalışanların kişiörgüt uyumları güçlenerek örgütlerin istedikleri tutum ve davranışlara sahip olmaları mümkün olabilecektir. 


\section{Kavramsal Çerçeve ve Hipotez Geliştirme}

\section{1. Örgüt Temelli Özsaygı}

Kavram olarak özsaygı, bireyin kendi yeterliliği ve değerliliğine ilişkin olarak yaptığı değerlendirmesidir (Rosenberg, 1965). Örgüt temelli özsaygı, özsaygı kavramının özel bir şekli olarak ele alınmaktadır (Gardner vd., 2004; Pierce ve Gardner, 2009). Örgüt temelli özsaygı, çalışanların örgütündeki rollerine katılarak ihtiyaçlarını karşılayabileceklerine inandıkları örgütteki durumuyla ilgili sahip oldukları pozitif bir duygu ve bilinçtir. Pierce, Gardner, Cummings ve Dunham da (1989) örgüt temelli özsaygının, çalışanların örgütlerinde yerine getirdikleri görevlerin karşıı̆ında kendi ihtiyaçlarını da karşılama durumundaki inanç düzeyini gösterdiğini ve örgüt temelli özsaygıları yüksek olanların kendilerini çalıştıkları örgütte önemli, anlamlı, etkili ve değerli algıladıklarını ifade etmişlerdir.

\section{2. İş Performansı}

Iş performansı, hem insan kaynakları hem de örgütsel davranış yazınında çok fazla çalışma yapılan konulardan birisidir. Çünkü bireysel düzlemde çalışanların yüksek iş performansları örgütlerin bağımlı olduğu önemli bir çıktı değişkenidir (Sykes ve Venkatesh, 2017). Çalışan performansı, belirli bir zaman periyodunda belirlenmiş hedef ve standartları gerçekleştirmeye ilişkin icra ettiği eylem ve faaliyetlerin neticesinde ulaştığı sonuçlar şeklinde ifade edilmektedir (Bingöl, 2014). Çalışanların belirlenen hedeflere ulaşması durumunda yüksek performanslı, hedeflenenin altında kalması durumunda ise düşük performanslı olarak adlandırılmaktadır.

\subsection{Psikolojik İyi Oluş}

Öznel iyi oluş, bireylerin genel olarak mutluluğu ne kadar hissettiklerine odaklanan bir bakış açısına, psikolojik iyi oluş ise bireylerin hayatlarından ne kadar memnuniyet duyduklarına, olumluluğu ve olumsuzluğu ne kadar yaşadıklarına yoğunlaşan bir bakış açısına sahip kavramdır (Deci ve Ryan, 2008). Psikolojik iyi oluş, kişinin birey olarak amaçlı bir yaşam içerisinde olup olmadığı, amaçlarına ulaşıp ulaşmadığı ve çevresindekilerle olan etkileşimlerinin niteliğine dair duyumsadıklarıdır (Ryff ve Keyes, 1995). Psikolojik iyi oluş, kişinin kendisine dair öznel tecrübesidir (Diener, 1994). Deci ve Ryan (2008) da kavramı, bireylerin yaşamlarında karşılaştıkları zorlukları yönetme konusundaki becerileri şeklinde tanımlamıştır. Dolayısıyla bireyler yaşamlarında başarabileceklerine yönelik kendilerine inanıyorlarsa, psikolojik iyi oluş düzeyleri de artacaktır (Wright, 2005). Ayrıca çalışanların psikolojik iyi oluşları sadece çalışanlar için değil aynı zamanda yöneticiler için de önemli bir konudur. Çünkü mutlu çalışanlar üretken sonuçlara neden olabilirken (Wright ve Staw, 1999), örgütlerdeki stres ise çalışanlar üzerinde depresyon, kaygı, pek çok fiziksel problem (Siu, Lu ve Spector, 2007) gibi olumsuz sonuçlara yol açabilmektedir.

\section{4. Çalışmaya Tutkunluk}

Yazındaki tartışmalarda hala güncelliğini sürdüren önemli konulardan biri olarak çalışmaya tutkunluk, "pozitif, tatmin edici, çalışmayla ilgili ruh hali" (Schaufeli vd., 2002) şeklinde ifade edilmektedir. Çalışmaya tutkun olanlar, enerjik, performans gösteren ve işini keyifle yerine getirenler olarak düşünüldükleri için (Özsoy, Filiz ve Semiz, 2013), buradaki esas konu çalışanların çalışma eyleminin verdiği tatmin duygusundaki ruh halleridir (Schaufeli, Bakker ve Salanova, 2006). Çalışmaya tutkunluk, motivasyonel bir süreç olarak dinçlik, adanmışlık ve yoğunlaşma şeklinde üçlü bir yapıda incelenmektedir (Schaufeli vd., 2002). Çalışmaya tutkunluk konusunun açıklanmasında Sosyal Mübadele Teorisi uygun bir alt yapı sağlamaktadır. Saks (2006), örgütlerin sağladığı kaynaklara karşılık olarak bireyler çalışmaya tutkun olabilmektedirler. Dolayısıyla bireysel ve örgütsel güçlerle donanmış çalışanlar kendilerinden beklenen iş taleplerini karşılamak için tutkunluk hissedeceklerdir. 


\subsection{Hipotez Geliştirme}

\section{Örgüt Temelli Özsaygının İ̧̧ Performansı ile ilişkisi}

Örgüt temelli özsaygının çalışan performansının açıklanmasında önemli bir konumda ve güçlü bir öngörücüsü olduğu ifade edilmektedir (Gardner vd., 2004; Pierce ve Gardner, 2004). Ayrıca yüksek özsaygı, çalışanların daha yüksek performans düzeyine ulaşmalarına yol açabilecek yüksek öz yeterlilikle de ilişkilidir (Gardner ve Pierce, 1998). Örgüt temelli özsaygılarının yüksek olmasının bir sonucu olarak çalışanların örgütlerine yönelik olumlu tutumlara sahip olabilmesi (Lee, 2003) ve içsel motivasyonunu pozitif olarak etkilemesi (Pierce vd., 1989; Hui ve Lee, 2000) ve böylece çalışanlardan yüksek performans göstermeleri beklenebilir. Gardner ve Pierce'nin (1998) çalışmasında örgüt temelli özsaygının performans üzerinde pozitif bir etkiye sahip olduğu ve Gardner vd.'nin (2004) çalışmasında örgüt temelli özsaygı ile performans arasında pozitif bir ilişki ve yapılan bir meta-analiz çalışmasında (Bowling vd., 2010) da, örgüt temelli özsaygı ile rol performansı arasında pozitif bir ilişki olduğu ortaya konulmuştur. Dolayısıyla yapılan açıklamalar ve çalışmalara dayanarak aşağıdaki temel hipotez geliştirilmiştir.

$\mathrm{H}_{1}$ : Örgüt temelli özsaygı iş performansı üzerinde pozitif ve anlamlı bir etkiye sahiptir.

\section{Örgüt Temelli Özsaygının Psikolojik İyi Oluş ile İlişkisi}

Örgüt temelli özsaygı, çalışanların örgütlerinde kendilerini beceri, değerlilik, etkililik, güvenilirlik açılarından değerlendirdiklerinde ulaştıkları kendileri ile ilgili beğenileridir (Akyüz, 2018). Bireylerin yaşamlarını genel olarak kaliteli değerlendirip değerlendirmemeleri ise, psikolojik iyi oluşlarına ilişkin bir sonuçtur. Olumlu değerlendirmeleri yaşam tatminlerinin yüksek, tersine ise yaşam tatminlerinin düşük olduğuna işarettir. Dolayısıyla örgüt temelli özsaygı, çalışanların psikolojik iyi oluşları için önemli bir güç olabilir. Yapılan çalışmalar da ileri sürülen bu ifadeyi desteklemektedir. Pierce vd. (2015), Awan ve Sitwat (2014) ile Akyüz'ün (2018) çalışmalarında örgüt temelli özsaygı ile psikolojik iyi oluş arasında pozitif bir ilişki olduğu ortaya konulmuştur.

\section{Psikolojik İyi Oluşun İ̧̧ Performansı ile i̇lişkisi}

Psikolojik iyi oluş bireyin mutluluğunu sağlayarak ve yaşam doyumu ve işteki stres faktörleri ile mücadelesinde başarılı olmasına katkıda bulunarak yaşam kalitesini arttırabilmektedir (Raich ve Ho, 2017). Kale (2013) tarafından yapılan çalışmada yaşam doyumu ile iş performansı, Alvi (2017) ile Wright ve Cropanzano (2000) tarafından yapılan çalışmalarda ise psikolojik iyi oluş ile iş performansı arasında pozitif bir ilişkinin varlığı ortaya konulmuştur. Lohapan'ın (2016) çalışmasında da psikolojik iyi oluşun iş başarısı üzerinde pozitif bir etkiye sahip olduğu bulunmuştur.

\section{Örgüt Temelli Özsaygının İş Performansına Etkisinde Psikolojik İyi Oluşun Aracılık Rolü}

Bireyin yaşamındaki mücadeleleri yönetme konusundaki becerisi (Deci ve Ryan, 2008) olarak tanımlanan psikolojik iyi oluş düzeyini artırmak için sahip olunan kaynakların içeriğini ve sayısını zenginleştirmek gerekmektedir. Psikolojik iyi oluş kavramının içeriğinde yer alan diğerleri ile nitelikli ilişkiler, çevresel hakimiyet, kararlarında özerklik, amaç edinme ve peşinden gitme, bireysel gelişim gibi alanlardaki bireyin başarısında, örgüt temelli özsaygısı önemli bir öncül olabilir. Yazında bu ifadeyi destekleyen çalışmalar söz konusudur (Awan ve Sitwat, 2014; Pierce vd., 2015; Akyüz, 2018). Dolayısıyla örgüt temelli özsaygı psikolojik iyi oluşu güçlendirerek iş performansı üzerinde etkili olabilir. Dolayısıyla yapılan açıklamalar ve çalışmalara dayanarak aşağıdaki hipotez geliştirilmiştir.

$\mathrm{H}_{2}$ : Psikolojik iyi oluş örgüt temelli özsaygı ile iş performansı arasındaki ilişkide aracılık etkisine sahiptir.

\section{Örgüt Temelli Özsaygının Çalışmaya Tutkunluk ile ilişkisi}

Örgütsel temelli özsaygının bireylerin çalışma ortamı ile ilişkilerinde olumlu bir öz değerlendirmeyi ifade etmesi nedeniyle, bireyin kendisi ile ilgili sahip olacağı değerlendirmesi örgütteki tutum ve olası davranışlarını şekillendirebilir. Dolayısıyla bireyin pozitif bir değerlendirmeye sahip olması, yüksek düzeyde tutkunluk sergilemesine yol açabilir. Rotich'in (2016) yaptığı çalışmada örgüt temelli özsaygı ile çalışmaya 
tutkunluk arasında pozitif bir ilişkiye ve Mauno, Kinnunen ve Ruokolainen (2007) tarafından yapılan çalışmada örgüt temelli özsaygının çalışmaya tutkunluğun ortaya çıkışında etkili olduğu sonucuna ulaşılmışır. Çalışmaya tutkunluk, motivasyonel bir süreç olarak değerlendirildiğinde (Schaufeli vd., 2002) ise örgüt temelli özsaygı içsel motivasyonu artırmaktadır (Hui ve Lee, 2000).

\section{Çalışmaya Tutkunluğun İş Performansı İle ilişkisi}

Tutkulu çalışanlar görevlerine bağlı ve kendi rollerinde tamamen aktiftirler (Kahn, 1990). Ayrıca bu tutkulu çalışanlar, görev performansında oldukça esnek olduklarından yüksek düzeyde zihinsel ve fiziksel enerji gösterirler, akıllarını ve ruhlarını işlerine katabilirler. İşlerine güçlü bir katılım sergiler ve işlerinden güçlü bir tutku, ilham, heyecan ve meydan okuma duygusu elde ederler ve bunu da işlerinde gösterirler. Bu özelliklerdeki çalışanlar için zamanın nasıl geçtiği fark edilmez ve dolayısıyla işlerine tamamen odaklanmışlardır (Schaufeli ve Bakker, 2004). Çalışmaya tutkulular, işlerinden zevk alır, daha iyi performans gösterir ve yüksek örgütsel bağlılık gösterirler (Salanova, Agut ve Peiró, 2005; Hakanen, Bakker ve Schaufeli, 2006). Tutkunluk, bireylerin amaçlarına ulaşmasını sağlayan iş performansları için motivasyonel bir yapıdır (Lohapan, 2016). Bakker ve Bal (2010) da, daha tutkulu olanların olmayanlara göre zamanla daha fazla performans ortaya koyabileceğini ifade etmiştir. Yazındaki çalışmalar çalışmaya tutkunluk ile iş performansı arasında önemli ilişkilerin olduğunu göstermektedir. Yapılan çalışmalarda iş performansının çalışmaya tutkunluğun pozitif sonuçlarından olduğu (Schaufeli ve Bakker, 2004), çalışmaya tutkunluk ile satış hacmi (Xanthopoulou, Bakker, Kantas, Demerouti ve Schaufeli, 2009), iş performansı (Salanova vd., 2005), rol performansı (Rich vd., 2010) ve yenilikçilik (Hakanen, Perhoniemi ve Toppinen-Tanner, 2008) arasında pozitif ilişkilerin olduğu ortaya konulmuştur.

\section{Örgüt Temelli Özsaygının İ̧̧ Performansına Etkisinde Çalışmaya Tutkunluğun Aracılık Rolü}

Örgüt temelli özsaygının bireyin örgütteki yeterliliklerine dair öz değerlendirmesi, başka bir deyişle bireyin kendisini anlaması yapabileceklerine ilişkin psikolojik bir gücü olarak değerlendirilebilir. İş performansı, çalışanlardan talep edilen davranışsal sonuçlardır. Çalışmaya tutkunluk ise motivasyonel bir süreci ifade eder ve bu süreci güçlendirmek için iş kaynaklarına ihtiyaç vardır. Bu kapsamda bireyin örgütündeki kendisine dair özsaygısı (kişisel bir güç olarak) motivasyon üzerinden performans artışına yol açabilir (Judge vd., 1998). Dolayısıyla yapılan açıklamalar ve çalışmalara dayanarak aşağıdaki hipotez ileri sürülmüştür:

$\mathrm{H}_{3}$ : Çalışmaya tutkunluk örgüt temelli özsaygı ile iş performansı arasındaki ilişkide aracılık etkisine sahiptir.

\section{Örgüt Temelli Özsaygının İş Performansına Etkisinde Psikolojik İyi Oluş ve Çalışmaya Tutkunluğun Seri Aracılık Rolü}

Psikolojik iyi oluş, bireyin yaşamında karşılaştığı anlamlı amaçların peşinden gitme, bireysel gelişim ve diğerleriyle güvenli ve kaliteli ilişkiler kurma, kendi ihtiyaçları kapsamında çevresel hakimiyet kurma, kendi kararını vermede özerk olma gibi varoluşa ilişkin mücadeleleri yönetmesi olarak ifade edilmiştir (Keyes, Shmotkin ve Ryff, 2002). Başka bir ifade ile birey yaşamında kendini gerçekleştirmeye yönelmektedir. Bireyin psikolojik iyi oluştaki yüksek düzeyi çalışmaya tutkunluğunu daha da artırabilir. Nitekim yapılan çalışmalarda psikolojik iyi oluş çalışmaya tutkunluğu pozitif olarak etkilemiştir (Aiello ve Tesi, 2017; Çankır ve Şahin, 2018;). Lohapan'ın (2016) çalışmasında da psikolojik iyi oluşun işe adanma üzerinde pozitif bir etkiye sahip olduğu ortaya konulmuştur.

Örgüt temelli özsaygının iş performansı üzerindeki etkisinde psikolojik iyi oluş ile çalışmaya tutkunluğun seri aracılık etkisine sahip olabileceği beklenmektedir. Çünkü yapılan yazın taramasında örgüt temelli özsaygının her iki aracı değişken için önemli bir kaynak olabileceği (Mauno vd., 2007; Pierce vd., 2015) ve ayrıca her iki aracı değişkenin de iş performansına etkisine dair yapılmış çalışmalar mevcuttur (Wright ve Cropanzano, 2000; Rich vd., 2010). Dolayısıyla aşağıdaki hipotez ileri sürülmüştür:

$\mathrm{H}_{4}$ : Psikolojik iyi oluş ile çalışmaya tutkunluk, örgüt temelli özsaygı ile iş performansı arasındaki ilişkide seri aracılık etkisine sahiptir. 
Örgüt temelli özsaygı, psikolojik iyi oluş, çalışmaya tutkunluk ve iş performansı arasında olduğu düşünülen ilişkileri ortaya koymak için ileri sürülen hipotezleri kapsayan araştırmanın modeli Şekil 1'de görülmektedir.

Şekil 1. Araştırmanın Modeli

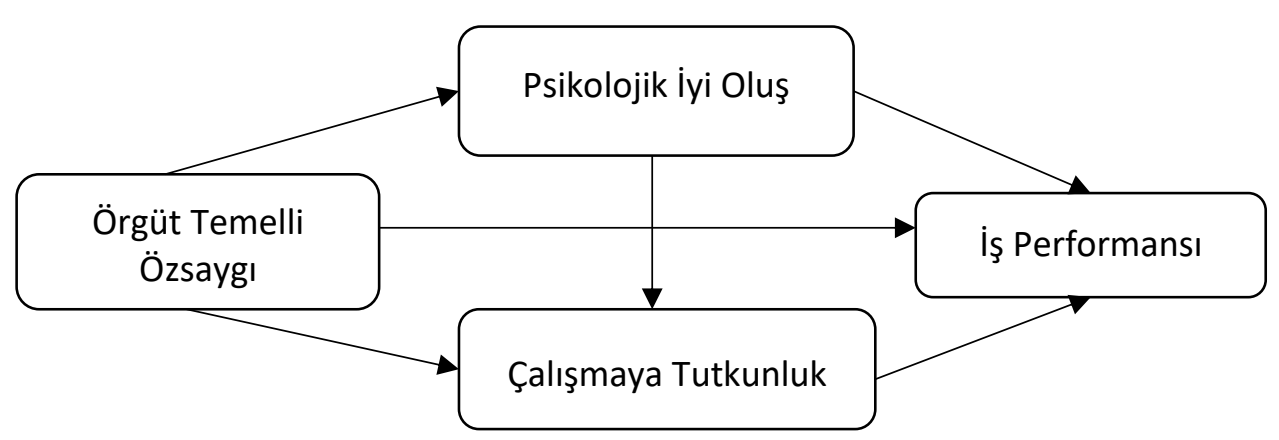

\section{Yöntem}

\section{1. Örnekleme Süreci}

Araştırmanın örneklemini İstanbul ilindeki gıda, temizlik, kozmetik gibi çeşitli alanlarda faaliyet gösteren firmalardan ankete katılan 370 çalışan oluşturmaktadır. Veriler kolayda örnekleme yöntemiyle anket tekniği kullanılarak toplanmıştır. Ana kitleden verilerin sağlanmasında kolaylığı, ekonomikliği ve hızııı̆̆ı dikkate alınarak kolayda örneklem yönteminin kullanılmasına karar verilmiştir (Haşıloğlu, Baran ve Aydın, 2015). Araştırmaya katılan örneklemin, \% 55'i erkek, \% 69'u lisans mezunu, yaş ortalaması 32,98, \%61'i evli olup, \%79'u alt düzey olarak çalışmaktadır.

\subsection{Araştırma Ölçeklerinin Oluşturulması}

Örgüt temelli özsaygının ölçümünde ise Pierce vd. (1989) tarafından geliştirilen 10 maddeli tek boyutlu örgüt temelli özsaygı ölçeği kullanılmıştır. Bu ölçekteki sorulardan birisi "Çalıştığım kurumda arkadaşlarımla uyumluyum" şeklindedir. illgili çalışmada ölçeğin güvenilirliği 0,91 olarak tespit edilmiştir.

Psikolojik iyi oluşunun ölçümünde Diener, Wirtz, Tov, Kim-Prieto, Choi, Oishi ve Biswas-Diener (2010) tarafından geliştirilen 8 ifadeli tek faktörlü bir yapı içeren Psikolojik İyi Oluş ölçeği kullanılmıştır. Bu ölçekteki sorulardan birisi "Günlük olarak gerçekleştirdiğim rutin faaliyetlerim benim için memnuniyet vericidir" şeklindedir. Psikolojik iyi oluş ölçeğinin ilgili çalışmadaki güvenilirliği 0,87 olarak bulunmuştur.

Çalışmaya tutkunluğun ölçümünde Schaufeli vd. (2006) tarafından geliştirilen çalışmaya tutkunluk ölçeğinin 9 maddeli kısa formu (Utrecht Work Engagement Scale-UWES-9) kullanılmıştır. 17 maddeli orijinal UWES'ten kısaltılmıştır. Ölçek, 3'er ifade ile temsil edilmekte; dinçlik, adanmışık ve yoğunlaşma olarak 3 alt boyuttan oluşmaktadır. Schaufeli vd. (2006), çalışmasında ölçeğin kısa formunun alt boyutlardan oluşmayan bir araştırma probleminin olması halinde tercih edilmesini tavsiye etmektedirler (akt. Özkalp ve Meydan, 2015). Bu ölçekteki sorulardan birisi "Işimde kendimi güçlü ve dinç hissederim" şeklindedir. Bu kısa formun güvenilirliği Turgut (2013) tarafından yapılan çalışmada 0,90 olarak hesaplanmıştır.

İş performansının ölçümünde ise öncesinde Kirkman ve Rosen'in (1999) daha sonra ise Sigler ve Pearson'ın (2000) çalışmasında kullandıkları 4 ifadeli tek boyutlu iş performansı ölçeği kullanılmıştır. Bu ölçekteki sorulardan birisi ise "Sunduğum hizmet kalitesinde standartlara fazlasıla ulaştığımdan eminim" şeklindedir. Çöl (2008) tarafından yapılan çalışmada ölçeğin güvenilirliği 0,82 olarak tespit edilmiştir.

Ankette katılımcıların ölçeklerdeki ifadelere ilişkin algılamalarının ölçümlemesi, 1=Kesinlikle katılmıyorum ve 5=Kesinlikle katılıyorum şeklinde 5’li Likert tipinde hazırlanan ölçeklerle yapılmıştır. 


\section{Bulgular}

\subsection{Geçerlilik ve Güvenilirlik Analizleri}

Değişkenlerin geçerlilik ve güvenilirliklerin ortaya konulmasında güvenilirlik, tek boyutluluk ve ayrışma geçerliliği testleri yapılmıştır. SPSS 23.0 ve SmartPLS istatistik programları kullanılarak öncelikle keşfedici faktör analizi ve sonrasında ise doğrulayıcı faktör analizi (DFA) yapıımıştır.

Örgüt temelli özsaygı ölçeğinin KMO değeri 0,892 ( $<<0,000)$; iş performansı ölçeğinin KMO değeri $0,802$ ( $p<0,000)$; psikolojik iyi oluş ölçeğinin KMO değeri $0,902(p<0,000)$ ve çalışmaya tutkunluk ölçeğinin KMO değeri ise $0,872(p<0,000)$ olarak bulunmuştur. KMO için kabul edilebilir kritik değer 0,50 olup (Field, 2000); tüm ölçeklerin hesaplanan KMO değerlerinin 0,50'nin üstünde olması nedeniyle faktör analizinin yapılmasına karar verilmiştir. Faktör analizinde çıkarım yöntemi olarak temel bileşen analizi, rotasyon yöntemi olarak ise Varimax kullanılmıştır. Yapılan analiz sonucunda örgüt temelli özsaygının on ifadesi toplam varyansın $\% 65,16$ 'sını, psikolojik iyi oluşun sekiz ifadesi toplam varyansın $\% 52,75^{\prime}$ ini, çalışmaya tutkunluğun dokuz ifadesi toplam varyansın \%59,60'ını ve iş performansının dört ifadesi toplam varyansın \%67,60'ını açıklamaktadır.

Tablo 1. Ölçeklerin Faktör ve Güvenirlik Analizi Sonuçları

\begin{tabular}{|c|c|c|c|c|}
\hline Değişkenler & Faktör Yükleri & Cronbach Alpha & AVE & CR \\
\hline Örgüt Temelli Özsaygı & & 0,917 & 0,575 & 0,931 \\
\hline ӧтӧ1 & 0,681 & & & \\
\hline ӧтӧ2 & 0,791 & & & \\
\hline ӧтӧз & 0,726 & & & \\
\hline ӧтӧ4 & 0,798 & & & \\
\hline ӧтÖ5 & 0,779 & & & \\
\hline ӧтӧ6 & 0,670 & & & \\
\hline ӧтӧ7 & 0,767 & & & \\
\hline ӧтӧ8 & 0,781 & & & \\
\hline ӧтÖ9 & 0,819 & & & \\
\hline ӧтӧ10 & 0,749 & & & \\
\hline Psikolojik İyi Oluş & & 0,874 & 0,534 & 0,901 \\
\hline PiO1 & 0,730 & & & \\
\hline PiO2 & 0,775 & & & \\
\hline PiO3 & 0,619 & & & \\
\hline PiO4 & 0,669 & & & \\
\hline PiO5 & 0,768 & & & \\
\hline Pio6 & 0,773 & & & \\
\hline Pio7 & 0,730 & & & \\
\hline PiO8 & 0,767 & & & \\
\hline Çalışmaya Tutkunluk & & 0,898 & 0,505 & 0,915 \\
\hline ÇT1 & 0,778 & & & \\
\hline ÇT2 & 0,777 & & & \\
\hline ÇT3 & 0,556 & & & \\
\hline ÇT4 & 0,779 & & & \\
\hline ÇT5 & 0,733 & & & \\
\hline ÇT6 & 0,714 & & & \\
\hline ÇT7 & 0,596 & & & \\
\hline ÇТ8 & 0,591 & & & \\
\hline ÇT9 & 0,606 & & & \\
\hline İş Performansı & & 0,847 & 0,686 & 0,897 \\
\hline iP1 & 0,852 & & & \\
\hline iP2 & 0,842 & & & \\
\hline ip3 & 0,858 & & & \\
\hline İP4 & 0,756 & & & \\
\hline
\end{tabular}


Keşifsel faktör analizi yapıldıktan sonra doğrulayıcı faktör analizi (CFA) yapılmıştır. Araştırma modelinde yer alan değişkenlerin faktör yükleri 0556 ile 0,858; hesaplanan ortalama varyans (AVE) 0,505 ile 0,686 ; bileşik güvenilirlik (CR) 0,897 ile 0,931 ve Cronbach Alfa $(\alpha)$ ise 0,847 ile 0,917 arasında değişmektedir. Hesaplanan AVE, CR ve Cronbach Alfa değerleri, Nunnally (1978) ve Fornell ve Larcker'in (1981) kritik değerlerini geçmektedir. Değişkenlerin ayrışma geçerliliğini sağlaması için, her bir değişkende AVE'nin hesaplanan karekökünün değişken çiftleri arasındaki korelasyonlardan büyük olması gerekmektedir (Fornell ve Larcker, 1981). Tablo 2'deki parantez içindeki değerler ayrışma geçerliliğine ilişkin bir sorun olmadığını göstermektedir. Dolayısıyla değişkenler yazınla tutarlı olarak tek boyutluluk ve gerekli geçerlilik ve güvenirlik şartlarını sağlamaktadır.

Değişkenler arasındaki ilişkilerin incelenmesinde korelasyon analizi yapılmıştır. Korelasyon analizinde, modeldeki değişkenlerin aralarında anlamlı ve çift yönlü ilişkiler ortaya çıkmıştır. Tablo 2'deki korelasyon sonuçlarına göre; örgüt temelli özsaygı ile psikolojik iyi oluş $(r=0,71, p<0,01)$, örgüt temelli özsaygı ile çalışmaya tutkunluk $(r=0,59, p<0,01)$ ve örgüt temelli özsaygı ile iş performansı $(r=0,64, p<0,01)$; psikolojik iyi oluş ile çalışmaya tutkunluk $(r=0,53, p<0,01)$, psikolojik iyi oluş ile iş performansı $(r=0,73, p<0,01)$ ve çalışmaya tutkunluk ile iş performansı $(r=0,50, p<0,01)$ arasında pozitif ilişkinin olduğu görülmektedir. Yapılan korelasyon analizi, incelenen değişkenler arasında pozitif yönlü bir ilişkinin varlığını ortaya koymaktadır.

Tablo 2. Ortalama, Standart Sapma ve Korelasyon Değerleri

\begin{tabular}{clcccccc}
\hline Sıra & \multicolumn{1}{c}{ Değişkenler } & 1 & 2 & 3 & 4 & Ort. & Ss. \\
\hline 1 & Örgüt Temelli Özsaygı & $(0,76)$ & & & & 4,13 & 0,5936 \\
2 & Psikolojik Iyyi Oluş & $0,71^{* *}$ & $(0,75)$ & & & 4,11 & 0,6228 \\
3 & Çalışmaya Tutkunluk & $0,59^{* *}$ & $0,53^{* *}$ & $(0,69)$ & & 3,98 & 0,5698 \\
4 & i̧ş Performansı & $0,64^{* *}$ & $0,73^{* *}$ & $0,50^{* *}$ & $(0,83)$ & 4,07 & 0,6823 \\
\hline
\end{tabular}

$\mathrm{N}: 370, * \mathrm{p}<0,05, * * \mathrm{p}<0,01$

\subsection{Hipotez Testleri}

Örgüt temelli özsaygının iş performansı üzerine etkisinde psikolojik iyi oluş ve çalışmaya tutkunluğun aracılık rollerinin analizinde Hayes'in (2009) geliştirdiği aracı değişken analiz yöntemi takip edilmiştir. Bu analizde seri çoklu analiz modeli kullanılmış olup, söz konusu bu model, 1 adet doğrudan ve 3 adet ise dolaylı etkiden oluşmaktadır. Bahsedilen etkiler; i) örgüt temelli özsaygının iş performansına etkisinde psikolojik iyi oluşun dolaylı etkisi (a1b1), ii) örgüt temelli özsaygının iş performansına etkisinde çalışmaya tutkunluğun dolaylı etkisi (a2b2) ve iii) örgüt temelli özsaygının iş performansına etkisinde psikolojik iyi oluş ve çalışmaya tutkunluğun dolaylı etkisinden ( $\mathrm{a} 1 \mathrm{~d} 1 \mathrm{~b} 2$ ) oluşmaktadır. Dolaylı etkilerin toplamına, örgüt temelli özsaygının iş performansına olan doğrudan etkisi eklendiğinde toplam etkiye ulaşılmaktadır (c). Toplam etkiye ilişkin formül ise $c=c^{\prime}+a 1 b 1+a 2 b 2+a 1 d 1 b 2$.

\section{Örgüt Temelli Özsaygının İş Performansı Üzerine Etkisi}

Örgüt temelli özsaygının iş performansı üzerine doğrudan etkisine yönelik analizde $\beta$ katsayısı 0,739 olarak ortaya çıkmıştır (Tablo 3). Dolayısıyla $\mathrm{H}_{1}$ hipotezi desteklenmiştir.

Tablo 3. Toplam Etki Analizi Sonucu

\begin{tabular}{|c|rcc|c|c|}
\hline Doğrudan Etki & \multicolumn{2}{|c|}{$\beta$} & SE & $p$ & $\begin{array}{c}\text { Bootstrap Güven Aralığı } \\
\text { BoLLCl BoULCl }\end{array}$ \\
\hline Örgüt Temelli Özsaygı $\rightarrow$ Iş̧ Performansı & 0,739 & 0,0459 & 0,000 & $0,6496-0,8300$ \\
\hline
\end{tabular}




\section{Örgüt Temelli Özsaygının İş Performansına Etkisinde Psikolojik İyi Oluş ve Çalışmaya Tutkunluğun} Seri Aracılık Rolü

Şekil 2'de, örgüt temelli özsaygı ve çalışmaya tutkunluğun psikolojik iyi oluş ile iş performansı arasındaki ilişkide seri aracılık etkisine dair a1, b1, a2, b2, d1 ve $c^{1}$ yolları gösterilmektedir.

Şekil 2. Seri Aracılık Rolüne Dair Model

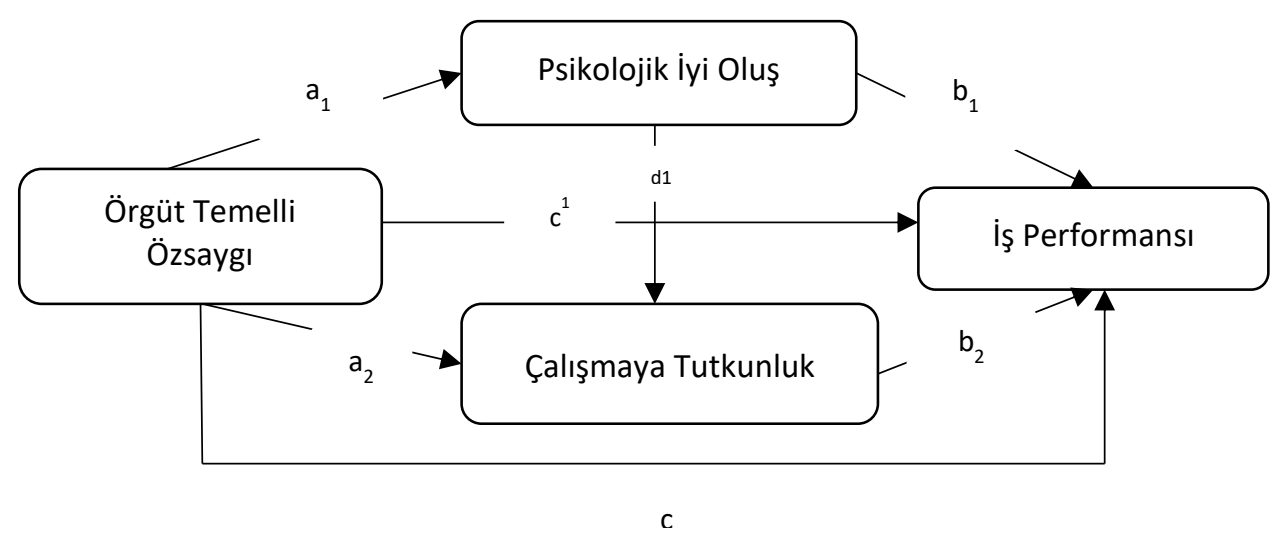

Şekil 2'de seri aracılık rolüne dair geliştirilen modeldeki 3 farklı dolaylı etki, SPSS programının PROCESS eklentisinde 5000 alt örneklemden (bootstrap samples) \% 95 güven aralığında ulaşılan istatistiksel analizlerle test edilmiştir. Aracılık rollerinin açıklanmasında ind1, ind2 ve ind3 ifadeleri kullanılmıştır. Ayrıca toplam etkiden doğrudan etkinin çıkarılması ile elde edilen dolaylı etkinin anlamlıı̆ı̆ın belirlenmesinde ise Bootstrap güven aralığındaki değerlere bakılması gerekecektir.

Tablo 4. Seri Aracılık Analiz Sonuçları

\begin{tabular}{|c|c|c|c|c|c|c|c|c|c|c|c|c|}
\hline \multirow{2}{*}{\multicolumn{2}{|c|}{ Öncül }} & \multicolumn{3}{|c|}{$\begin{array}{c}\text { Aracı } 1 \\
\text { (Psikolojik İyi Oluş) }\end{array}$} & \multicolumn{4}{|c|}{$\begin{array}{c}\text { Aracı } 2 \\
\text { (Çalışmaya Tutkunluk) }\end{array}$} & \multicolumn{4}{|c|}{$\begin{array}{l}\text { Bağımlı Değişken } \\
\text { (İş Performansı) }\end{array}$} \\
\hline & & $\beta$ & SE & $p$ & & $\beta$ & SE & $\mathrm{p}$ & & $\beta$ & SE & $p$ \\
\hline $\begin{array}{c}\text { Bağımsız } \\
\text { Değişken } \\
\text { (Örgüt Temelli } \\
\text { Özsaygı) }\end{array}$ & a1 & 0,751 & 0,0382 & 0,000 & a2 & 0,415 & 0,0570 & 0,000 & $c^{1}$ & 0,216 & 0,0597 & 0,000 \\
\hline $\begin{array}{c}\text { Aracı } 1 \\
\text { (Psikolojik İyi } \\
\text { Oluş) }\end{array}$ & & --- & --- & --- & $\mathrm{d} 1$ & 0,200 & 0,0543 & 0,000 & b1 & 0,601 & 0,0541 & 0,000 \\
\hline \multirow[t]{3}{*}{$\begin{array}{c}\text { Aracı } 2 \\
\text { (Çalışmaya } \\
\text { Tutkunluk) }\end{array}$} & & -- & -- & -- & & --- & --- & -- & b2 & 0,127 & 0,0511 & 0,013 \\
\hline & \multicolumn{4}{|c|}{$R^{2}=0,51$} & \multicolumn{4}{|c|}{$R^{2}=0,37$} & \multicolumn{4}{|c|}{$R^{2}=0,58$} \\
\hline & \multicolumn{4}{|c|}{$\begin{array}{c}F(1,368)=387,662 \\
p=0,000\end{array}$} & \multicolumn{4}{|c|}{$\begin{array}{c}F(2,367)=107,816 \\
p=0,000\end{array}$} & \multicolumn{4}{|c|}{$\begin{array}{c}F(3,366)=168,8452 \\
p=0,000\end{array}$} \\
\hline
\end{tabular}

Birinci dolaylı etki, örgüt temelli özsaygının iş performansını psikolojik iyi oluş aracılı̆̆ıyla etkilediğidir (örgüt temelli özsaygı $\rightarrow$ psikolojik iyi oluş $\rightarrow$ iş performansı); a1b1 $=0,751(0,601)=0,451$ "ind1". Hesaplanan dolaylı etkinin yaklaşık \%45 seviyesinde olduğu görülmektedir. Dolaylı etkinin anlamlılığı için Bootstrap güven aralığı istatistik değerleri kontrol edilmektedir. Sonuçlar kontrol edildiğinde, alt ve üst sınır sıfııın üstünde olduğu için $((0,3086)-(0,5834))$ dolaylı etki anlamlıdır. Ulaşılan bu sonuç, örgüt temelli özsaygının psikolojik iyi oluşu artırdığı (a1 pozitif) ve psikolojik iyi oluştaki artışın da iş performansının yükselmesinde çalışmaya tutkunluktan ayrı bir rol üstlendiğini göstermektedir (b1 pozitif). Dolayısıyla $\mathrm{H}_{2}$ hipotezi desteklenmiştir. 
İkinci dolaylı etki, örgüt temelli özsaygının iş performansını çalışmaya tutkunluk aracılığıyla etkilediğidir (örgüt temelli özsaygı $\rightarrow$ çalışmaya tutkunluk $\rightarrow$ iş performansı); a2b2 =0,415 $(0,127)=0,053$ "ind2". Hesaplanan dolaylı etkinin yaklaşık \%5 seviyesinde olduğu görülmektedir. Dolaylı etkinin anlamlılığı için Bootstrap güven aralığı istatistik değerleri kontrol edilmektedir. Sonuçlar kontrol, edildiğinde alt ve üst sınır sıfııın üstünde olduğu için $((0,0166)-(0,1006))$ dolaylı etki anlamlıdır. Ulaşılan bu sonuç, örgüt temelli özsaygının çalışmaya tutkunluğu artırdığı (a2 pozitif) ve çalışmaya tutkunluktaki artışın da iş performansının yükselmesinde psikolojik iyi oluştan ayrı bir rol yüklendiğini göstermektedir (b2 pozitif). Dolayısıyla $\mathrm{H}_{3}$ hipotezi desteklenmiştir.

"Ind3" ifadesiyle gösterilen üçüncü dolaylı etki olan seri etki ise, örgüt temelli özsaygının iş performansını psikolojik iyi oluş ve çalışmaya tutkunluk aracılığıyla etkilemesi sonucu ortaya çıkmaktadır (örgüt temelli özsaygı $\rightarrow$ psikolojik iyi oluş $\rightarrow$ çalışmaya tutkunluk $\rightarrow$ iş performansı). a1d1b2 $=$ $0,751(0,200) 0,127=0,019$. Hesaplanan seri aracılık etkisinin yaklaşık $\% 2$ seviyesinde olduğu görülmektedir. Söz konusu etkinin anlamlılığı için Bootstrap güven aralığı istatistik değerleri kontrol edilmektedir. Sonuçlar kontrol edildiğinde, alt ve üst sınır sıfırın üstünde olduğu için $((0,0029)-(0,0495))$ dolaylı etki anlamlıdır. Ulaşılan bu sonuç, örgüt temelli özsaygının psikolojik iyi oluşu artırdığı (a1 pozitif), psikolojik iyi oluştaki artışın çalışmaya tutkunluğu güçlendirmekte (d1 pozitif) ve çalışmaya tutkunluğun da iş performansının yükselmesinde pozitif bir rol üstlendiğini göstermektedir (b2 pozitif). Dolayısıyla $\mathrm{H}_{4}$ hipotezi desteklenmiştir.

\section{Sonuç, Tartışma ve Öneriler}

Yazında, çalışanların iş performansı üzerinde etkili olabilecek faktörlerin incelenmesi önemli konular arasında yer almaktadır. İ̧ performansının arttırılabilmesinde örgütsel ve bireysel faktörler etkili olmaktadır. Bu çalışma kapsamında iş performansı üzerinde etkili olan örgüt temelli özsaygı, psikolojik iyi oluş ve çalışmaya tutkunluk değişkenleri incelenmiştir. Başka bir deyişle bu çalışmada, bağımsız ve bağımlı değişken arasında iki adet aracı değişkenin rolü yazında nadir görülen (Tilki, 2017) seri aracılık analizi ile incelenmiştir. Sonuçlar genel olarak değerlendirildiğinde, örgüt temelli özsaygı iş performansının ortaya çıkışında önemli bir güçlendiren ve psikolojik iyi oluş ile çalışmaya tutkunluk da bu ilişkide seri aracılık rolünü üstlenmiştir.

Çalışanların araştırmanın temel değişkenlerine dair algılamaları incelendiğinde, örgüt temelli özsaygı, psikolojik iyi oluş ve iş performansı düzeyleri katılıyorum ve kesinlikle katlıyorum arasında olup, yüksek düzeye yakındır. Çalışmaya tutkunluk düzeyleri ise karasızım ile katılıyorum arasında olup, ortalamanın üzerinde ortaya çıkmıştır. Dolayısıyla örneklemin değişkenlere ilişkin algılamaları, yüksek seviyede pozitif olarak gerçekleşmiştir.

Çalışmanın en temel bulgusu, örgüt temelli özsaygının iş performansı üzerinde pozitif etkiye sahip olduğudur. Yüksek örgüt temelli özsaygıya sahip çalışanlar kendilerini değerli, anlamlı, etkili olarak değerlendirdikleri ve bu değerlendirmenin öz yeterliliklerinin artışında psikolojik bir güce sahip olabilmesi nedeniyle, çalışanların örgütün beklediği davranışsal sonuçları karşılamaları mümkün olabilmektedir. Ulaşılan söz konusu bu temel bulgu, Gardner ve Pierce (1998), Gardner vd. (2004) ve Bowling vd.'nin (2010) çalışmalarındaki sonuçlarla tutarlıdır.

Çalışmada aracı değişkenlere ilişkin olarak ulaşılan bulgulardan birisi, örgüt temelli özsaygının iş performansına etkisinde psikolojik iyi oluşun kısmi aracılık rolü üstlendiğidir. Psikolojik iyi oluş örgüt temelli özsaygının iş performansı üzerine etkisinde kısmi olarak güçlendirici bir etkileyen olarak ortaya çıkmıştır. Örgüt temelli özsaygı psikolojik bir donanım olarak bireyin yaşamında karşılaştığı zorlukların üstesinden gelebilmesinde önemli bir öncül olmaktadır. Mücadele becerisi ve yaşam doyumu artmış bireyin performansının yüksek olması mantıklıdır. Ayrıca stresin sonuçlarıyla mücadele etmesi ve başarılı olması da yüksek intimaldir. Dolayısıyla psikolojik iyi oluş, örgüt temelli özsaygı ile iş performansı ilişkisini güçlendirmiştir. Yapılan çalışmalarda örgüt temelli özsaygının psikolojik iyi oluşu artırdı̆̆ı (Awan ve Sitwat, 2014; Pierce vd., 2015; Akyüz, 2018) ve psikolojik iyi oluş ile iş performansı arasında da pozitif bir ilişki olduğu (Wright ve Cropanzano, 2000; Kale, 2013; Raich ve Ho, 2017; Lohapan, 2016; Alvi, 2017) ortaya konulmuştur.

Çalışmada aracı değişkenlere ilişkin ulaşılan bulgulardan diğeri ise, örgüt temelli özsaygının iş performansına etkisinde çalışmaya tutkunluğun kısmi aracılık rolü üstlendiğidir. Çalışmaya tutkunluk örgüt 
temelli özsaygı ile iş performansı arasındaki ilişkiyi güçlendirmektedir. Çalışanın kendisinden beklenen iş taleplerinin karşılanmasında örgüt temelli özsaygının ortaya çıkardığı bireysel pozitif güç, çalışmaya tutkunluğu artırarak önemli bir rol üstlenmektedir. Tutkunluğu artmış bir çalışanın da kendisinden beklenilen davranışları karşılaması mümkün olabilmektedir. Yapılan çalışmalarda örgüt temelli özsaygının çalışmaya tutkunluğu artırdığı (Mauno vd., 2007; Rotich, 2016) ve çalışmaya tutkunluğun da performansını artırdığı (Schaufeli ve Bakker, 2004; Salanova vd., 2005; Hakanen vd., 2008; Xanthopoulou vd., 2009; Rich vd., 2010) ortaya konulmuştur. Ayrıca yapılan yazın taramasında çalışmaya tutkunluğun örneğin, Karatepe ve Demir (2014) çalışmasında, öz kendilik değerlendirmesi (bileşenlerinden birisi özsaygı) ile aile-iş birliği ve iş-aile birliği arasında ve Rich vd.'nin (2010) çalışmasında öz kendilik değerlendirmesi ile görev performansı arasındaki ilişkide tam aracılık rolü üstlendiği ortaya konulmuştur.

Çalışmada ulaşılan bulgulardan bir diğeri ise, örgüt temelli özsaygının iş performansına etkisinde psikolojik iyi oluş ve çalışmaya tutkunluğun seri aracılık rolüne sahip olduğudur. Çalışanların örgüt temelli özsaygıları psikolojik iyi oluşlarını, psikolojik iyi oluşları ise çalışmaya tutkunluklarını artırarak iş performanslarını yükseltebilmektedir. Örgüt temelli özsaygı psikolojik iyi oluş ve çalışmaya tutkunluk üzerinden iş performansında bir artışa yol açabilmektedir.

Çalışmanın ortaya koyduğu sonuçların pratikte insan kaynakları yöneticileri açısından önemi büyüktür. Örgütlerin çalışanlarından bekledikleri en önemli çıktı, yüksek iş performansıdır. Bu çalışmada da örgüt temelli özsaygı, psikolojik iyi oluş ve çalışmaya tutkunluk değişkenleri iş performansı üzerinde önemli düzeyde bir yordayıcılık gücüne sahiptir. Ayrıca, örgüt temelli özsaygı, psikolojik iyi oluş ve çalışmaya tutkunluk değişkenleri ile iş performansı arasında pozitif ilişkilerin varlığı söz konusudur. Birey söz konusu bu özellikler bakımından yüksek bir algılamaya sahip ise, davranışsal sonuçları örgütlerin beklentileri yönünde olabilecektir. Ayrıca örgüt temelli özsaygının bireyin örgüt içindeki tecrübelerine dayanarak zamanla gelişebilmesi, bireysel ve örgütsel kaynaklarla bireyin çalışmaya tutkunluğunun ortaya çıkabilmesi ve bireyin örgüt içerisinde mücadelesi, özerkliği, nitelikli ilişkileri, bireysel gelişimi gibi konuların doğrudan uygulamayla ilişkisi; yöneticilerin bu üç değişkenle ilgili olarak yapabileceklerinin olduğunu ortaya koymaktadır. Yöneticiler bireyleri yetkilendirerek, eğitime göndererek, takım çalışmalarını ön plana çıkararak örgüt temelli özsaygı ve çalışmaya tutkunlukları ve böylece zorlukları yönetme konusundaki beceri seviyeleri daha da artırılabilir.

Yapılan bu çalışmanın sonuçları sahip olduğu çeşitli kısıtlarıyla değerlendirilmelidir. Araştırma verileri tek bir zaman kesitinde toplanmış olup, sadece İstanbul ilinde özel sektördeki gıda, temizlik, kozmetik firmalarından ankete katılanlarla sınırlıdır. Yapılacak sonraki çalışmalarda farklı ve daha geniş örneklemler üzerinde bu çalışmanın değişkenleri yanında örgüt temelli özsaygının öncülleri ve örgütler açısından önemli olan yenilikçilik ve yaratıcılık ardıllarının da modele katıldığı araştırmalar yapılabilir. Ayrıca pozitif örgütsel davranışın önemli kavramları olarak değerlendirildiğinde ise bireylerin söz konusu özelliklerinin farklı zamanlardaki (boylamsal çalışmalar) durumlarının çeşitli performans kriterlerine etkisi ve böylece uygulanan insan kaynakları faaliyetlerinin de etkisi incelenmiş olabilir.

\section{Son Notlar}

* Bu çalışma, 28-29-30 Kasım 2018 tarihlerinde düzenlenen "IV. International Conference on Applied Economics and Finance \& Extended with Social Sciences (ICOAEF'18)" kongresinde sözlü olarak sunulmuş ve öz kısmı Bildiri Özetleri Kitabında yayınlanmıştır.

\section{Kaynaklar}

Aiello, A., \& Tesi, A. (2017). Psychological well-being and work engagement among Italian social workers: Examining the mediational role of job resources. Social Work Research, 41(2), 73-83.

Akyüz, M. (2018). Duygusal emek örgüt temelli öz-saygı ve yaşam tatminini etkiler mi? Işletme Araştırmaları Dergisi, $10(4), 170-186$. 
Örgüt Temelli Özsaygının İş Performansına Etkisinde Psikolojik İyi Oluş ve Çalışmaya Tutkunluğun Aracılık Rolü

Alvi, U. (2017). The effect of psychological wellbeing on employee job performance: Comparison between the employees of projectized and non-projectized organizations. Journal of Entrepreneurship \& Organization Management, 6(1), 1-6.

Awan, S., \& Sitwat, A. (2014). Workplace spirituality, self-esteem, and psychological well-being among mental health professionals. Pakistan Journal of Psychological Research, 29(1), 125-149.

Bakker, A. B., \& Demerouti, E. (2008). Towards a model of work engagement. Career Development International, 13(3), 209-223.

Bakker, A. B., \& Leiter, M. P. (2010). Where to go from here: Integration and future research on work engagement. In Bakker, A. B. \& Leiter, M. P. (Eds.), Work Engagement: A Handbook of Essential Theory and Research (181-196). New York, NY: Psychology Press.

Bakker, A. B., \& Bal, P. M. (2010). Weekly work engagement and performance: A study among starting teachers. Journal of Occupational and Organizational Psychology, 83(1), 189-206.

Bingöl, D. (2014). Insan kaynakları yönetimi (9. baskı). Ankara: Beta Basım Yayınları.

Bowling, N. A., Eschleman, K. J., Wang, Q., Kirkendall, C., \& Alarcon, G. (2010). A meta-analysis of the predictors and consequences of organization-based self-esteem. Journal of Occupational and Organizational Psychology, 83, 601-626.

Çankır, B., \& Şahin, S. (2018). Psychological well-being and job performance: The mediating role of work engagement. Hitit University Journal of Social Sciences Institute, 11(3), 2549-2560.

Çöl, G. (2008). Algılanan güçlendirmenin işgören performansı üzerine etkileri. Doğuş Üniversitesi Dergisi, 9(1), 35-46.

Deci, E. L., \& Ryan, R. M. (2008). Hedonia, eudaimonia, and well-being: An introduction. Journal of Happiness Studies, 9 , 1-11.

Diener, E. (1994). Assessing subjective well-being: Progress and opportunities. Social Indicators Research, 31, $103-157$.

Diener, E., Wirtz, D., Tov, W., Kim-Prieto, C., Choi, D., Oishi, S., \& Biswas-Diener, R. (2010). New well-being measures: Short scales to assess flourishing and positive and negative feelings. Soc Indic Res, 97, 143-156.

Field, A. P. (2000). Discovering statistics using spss for windows. London: Sage Publications.

Fornell, C., \& Larcker, D. F. (1981). Evaluating structural equation models with unobservable variables and measurement error. Journal of Marketing Research, 18, 39-50.

Garcea, N., Harrington, S., \& Linley, P. A. (2010). Building positive organizations. In Linley, P. A. Harrington, S., \& Garcea, N. (Eds.), Oxford Handbook of Positive Psychology and Work (323-333). New York: Oxford University Press.

Gardner, D. G., \& Pierce, J. L. (1998). Self-esteem and self-efficacy within the organizational context. Group and Organization Management, 23(1), 48-70.

Gardner, D. G., Van Dyne, L., \& Pierce, J. L. (2004). The Effects of pay level on organization-based self-esteem and performance: A field study. Journal of Occupational and Organizational Psychology, 77(3), 307-322.

Hahn, H., \& Mathews, M. A. (2018). Learning behaviors as a linkage between organization-based self-esteem and inrole performance. Journal of Management \& Organization, 1-16, doi:10.1017/jmo.2018.17

Hakanen, J. J., Bakker, A. B., \& Schaufeli, W. B. (2006). Burnout and work engagement among teachers. Journal of School Psychology, 43(6), 495-513.

Hakanen, J. J., Perhoniemi, R., \& Toppinen-Tanner, S. (2008). Positive gain spirals at work: From job resources to work engagement, personal initiative and work-unit innovativeness. Journal of Vocational Behavior, 73(1), 78-91.

Haşıloğlu, S. B., Baran, T., \& Aydın, O. (2015). Pazarlama araştırmalarındaki potansiyel problemlere yönelik bir araştırma: Kolayda örnekleme ve sıklık ifadeli ölçek maddeleri. Pamukkale Iş̧letme ve Bilişim Yönetimi Dergisi, 2(1), 19-28.

Hayes, A. F. (2009). Beyond Baron and Kenny: Statistical mediation analysis in the new millennium. Communication Monographs, 76(4), 408-420.

Hui, C., \& Lee, C. (2000). Moderating effects of organizationbased self-esteem on organizational uncertainty: Employee response relationships. Journal of Management, 26(2), 215-232.

Judge, T. A., Erez, A., \& Bono, J. E. (1998). The power of being positive: The relation between positive self-concept and job performance. Human Performance, 11, 167-187.

Kahn, W. A. (1990). Psychological conditions of personal engagement and disengagement at work. Academy of Management Journal, 33(4), 692-724.

Kale, E. (2013). Konaklama işletmelerinde öz uyumun iş performansına etkisi: Yaşam doyumunun aracı rolü. Yönetim Bilimleri Dergisi, 11(21), 117-133. 
Karatepe, O. M., \& Demir, E. (2014). Linking core self-evaluations and work engagement to work-family facilitation: A study in the hotel industry. International Journal of Contemporary Hospitality Management, 26(2), 307-323.

Keyes, C. L. M., Shmotkin, D., \& Ryff, C. D. (2002). Optimizing well-being: The empirical encounter of two traditions. Journal of Personality and Social Psychology, 82(6), 1007-1022.

Kirkman, B. L., \& Rosen, B. (1999). Beyond self-management: Antecedents and consequences of team empowerment. Academy of Management Journal, 42(1), 58-74.

Lee, J. (2003). An analysis of the antecedents of organization based self esteem in two Korean banks. Human Resources Management, 14(6), 1046-1066.

Lohapan, N. (2016). Psychological well-being and job success: An empirical research of tax auditors in Thailand. The Business and Management Review, 7(5), 95-104.

Mauno, S., Kinnunen, U., \& Ruokolainen, M. (2007). Job demands and resources as antecedents of work engagement: A longitudinal study. Journal of Vocational Behavior, 70, 149-171.

Nunnally, J. C. (1978). Psychometric theory. New York: McGraw Hill.

Özkalp, E., \& Meydan, B. (2015). Schaufeli ve Bakker tarafından geliştirilmiş olan işe angaje olma ölçeğinin Türkçe'de güvenilirlik ve geçerliliğinin analizi. İş, Güç Endüstri Iliş̧ileri ve Insan Kaynakları Dergisi, 17(3), 4-19.

Özsoy, E., Filiz, B., \& Semiz, T. (2013). İşkoliklik ve çalışmaya tutkunluk arasındaki ilişkiyi belirlemeye yönelik sağlık sektöründe bir araştırma. Sosyal ve Beşeri Bilimler Dergisi, 5(2), 59-68.

Pierce, J. L., Gardner, D. G., Cummings, L. L., \& Dunham, R. B. (1989). Organization-based self-esteem: Construct definition, measurement, and validation. Academy of Management Journal, 32, 622-648.

Pierce, J. L., \& Gardner, D. G. (2004). Self-esteem within the work and organizational context: A review of the organization-based self-esteem literature. Journal of Management, 30(5), 591-622.

Pierce, J. L., \& Gardner, D. G. (2009). Relationships of personality and job characteristics with organization-based selfesteem. Journal of Managerial Psychology, 24(5), 392-409.

Pierce, J. L., Gardner, D. G., \& Crowley, C. (2015). Organization-based self-esteem and well-being: Empirical examination of a spillover effect. European Journal of Work and Organizational Psychology, DOI: 10.1080/1359432X.2015.1028377.

Raich, A., \& Ho, R. (2017). Job performance and psychological well-being of Thai hotel workers: A multi-model path analytic study. Scholar: Human Sciences, 9(2), 147-163.

Rich, B. L., Lepine, J. A., \& Crawford, E. R. (2010). Job engagement: Antecedents and effects on job performance. Academy of Management Journal, 53(3), 617-635.

Rosenberg, M. (1965). Society and the adolescent self-Image. Princeton, NJ: Princeton University Press.

Rotich, R. K. (2016). The impact of organizational-based self esteem on work engagement among state corporations employees in Kenya. European Journal of Business and Management, 8(15), 114-126.

Ryff, C. D., \& Keyes, C. L. M. (1995). The structure of psychological well-being revisited. Journal of Personality and Social Psychology, 69, 719-727.

Saks, A. M. (2006). Antecedents and consequences of employee engagement. Journal of Managerial Psychology, 21(7), 600-619.

Salanova, M., Agut, S., \& Peiró, J. M. (2005). Linking organizational resources and work engagement to employee performance and customer loyalty: The mediation of service climate. Journal of Applied Psychology, 90(6), 12171227.

Seligman, M. (2011). Flourish. New York: Free Press.

Schaufeli, W. B., Salanova, M., González-Romá, V., \& Bakker, A. B. (2002). The measurement of engagement and burnout: A two sample confirmatory factor analytic approach. Journal of Happiness Studies, 3, 71-92.

Schaufeli, W. B., \& Bakker, A. B. (2004). Job demands, job resources and their relationship with burnout and engagement: A multi-sample study. Journal of Organizational Behavior, 25, 293-315.

Schaufeli, W. B., Bakker, A. B., \& Salanova M. (2006). The measurement of work engagement with a short questionnaire a cross-national study. Educational and Psychological Measurement, 66(4), 701-716.

Sigler, T. V., \& Pearson, C. M. (2000). Creating an empowering culture: Examining the relationship between organizational culture and perceptions of empowerment. Journal of Quality Management, 5(1), 27-52.

Siu, O. L., Lu, C. Q., \& Spector, P. E. (2007). Employees' well-being in greater China: The direct and moderating effects of general self-efficacy. Applied Psychology: An International Review, 56(2), 288-301. 
Sykes, T. A., \& Venkatesh, V. (2017). Explaining post-implementation employee system use and job performance: Impacts of the content and source of social network ties. MIS Quarterly, 41(3), 917- 936.

Tilki, T. Z. Ö. (2017). Yıldırma, örgütsel sinizm, iş doyumu ve işten ayrılma niyeti ilişkilerinde seri aracılık etkileri: Örgütlerde engelli çalışanlar üzerine bir araştırma. Hacettepe Üniversitesi SBE, Yayımlanmamış Yüksek Lisans Tezi, Ankara.

Turgut, T. (2013). Başarı hedef yönelimleri ve iş özelliklerinin çalışmaya tutkunluk üzerindeki katkıları. İstanbul Üniversitesi İşletme Fakültesi Dergisi, 42(1), 1-25.

Wadhawan, K. (2016). Psychological well-being as a predictor to job performance and job satisfaction. International Journal of Academic Research and Development, 1(3), 1-3.

Wright, T. A., \& Staw, B. M.( 1999). Affect and favorable work outcomes: Two longitudinal tests of the happy-productive worker thesis. Journal of Organizational Behavior, 20(1), 1-23.

Wright, T. A., \& Cropanzano, R. (2000). Psychological well-being and job satisfaction as predictors of job performance. Journal of Occupational Health Psychology, 5(1), 84-96.

Wright, T. A. (2005). The role of "happiness" in organizational research: Past, present and future directions. In Perrewe, P. L. \& Ganster, D. C. (Eds.), Research in Occupational Stress and Well-being. (4, 225-268). Amsterdam: JAI.

Xanthopoulou, D,, Bakker, A. B., Kantas, A., Demerouti, E., \& Schaufeli, W. B. (2009). Work engagement and financial returns: A diary study on the role of job and personal resources. Journal of Occupational and Organizational Psychology, 82(1), 183-200. 